\title{
Peran Partisipan sebagai Bagian Infrastruktur Seni di Sumatera Barat: Perkembangan Seni Musik Talempong Kreasi
}

\author{
Ardipal $^{1}$ \\ Jurusan Sendratasik, Fakultas Bahasa dan Seni, Universitas Negeri Padang
}

\begin{abstract}
ABSTRAK
Perkembangan seni tidak lepas dari peran pelaku seni atau seniman musik. Namun peran itu bukan hanya terletak pada seniman, tetapi juga berbagai unsur yang terlibat dalam kesenian dalam masyarakat atau partisipan seni, yang terlihat dalam infrastruktur seni. Penelitian ini menggunakan pendekatan deskriptif analisis, dengan maksud memberikan gambaran partisipan seni sebagai bagian dari infrastruktur seni dalam konteks kesenian Talempong Kreasi. Penelitian ini dilakukan untuk menjawab pertanyaan siapa yang berperan dan apa yang dilakukan mereka dalam musik talempong tradisi. Hasil penelitian ini menunjukkan bahwa talempong tradisi berhasil dikembangkan oleh tokoh partisipan akademik. Pengembangan ini terlihat dari konsep harmoni dalam komposisi musik dan penggabungan alat musik baru dan tradisi sehingga lahirlah Talempong Kreasi. Genre musik ini dapat berfungsi untuk pembentuk imaji dan identitas Minangkabau di masyarakat. Di antara permasalahan baru yang timbul, karena hasilnya masih berfokus kepada produksi musik komersial, bukan pada kualitas musik.
\end{abstract}

Kata kunci: Partisipan Seni, Perkembangan Seni, Talempong Kreasi

\begin{abstract}
The Participants Role as a Part of the Arts Infrastructure in West Sumatra: The Development of Talempong Kreasi Musical Arts. The development of art cannot be separated from the role of performers or musical artists. But the role does not merely only lie in the artists themselves, but also in the various elements involved in the arts in the community or the participants of art, which are commonly visible in the arts infrastructure. This study used a descriptive analytical approach, with the intention of giving the participants an overview of art as a part of the infrastructure of the art in the context of Talempong Kreasi art. This study was conducted to answer the questions of who play the role, and what they have done for Talempong music tradition. These results indicate that the tradition of talempong has successfully been developed by the academic participants. This development can be seen from the concept of harmony in the music composition and the incorporation of new and traditional music instruments so that the the tradition of Talempong Kreasi is emerged. This genre of music can be served for forming the image and Minangkabau identity in the society. Among the new problems that arise, the result still focuses on the production of commercial music, not on the quality of the music.
\end{abstract}

Keywords: Art Participant, Art Development, Talempong Kreasi

\section{Pendahuluan}

Berdasarkan hasil penelitian ini, dalam masyarakat tradisional, partisipan yang terlibat dalam kesenian, bisa bersifat individu, atau bersifat kolektif (semua anggota masyarakat). Penelitian ini memberikan gambaran partisipan seni sebagai bagian dari infrastruktur seni dalam konteks kesenian Talempong Kreasi. Dalam penelitian ini partisipan yang diteliti dibatasi pada oartisipan akademis. Hal ini dilakukan berangkat dari asumsi bahwa golongan nonakademik, sedikit

Alamat korespondensi: Prodi Seni Drama Tari, dan Musik - Universitas Negeri Padang. Jln. Prof. Dr. Hamka, Air Tawar, Padang 25131, Sumatra Barat. E-mail: ardipalarly@ymail.com; HP: 08126719483 
banyaknya dipengaruhi oleh golongan akademik, bukan sebaliknya. Kehidupan seni di masyarakat dapat didekati dengan menggunakan kacamata ilmu sosiologi atau biasa disebut dengan sosiologi seni sebagaimana ditulis oleh Dasilva (1984), yang dipelajari atau yang dikaji bukan hanya seni melainkan juga masyarakat atau kelompok masyarakat yang mengembangkan kesenian tersebut. Demikian juga seperti yang dikemukakan Warriner (1956) tentang pentingnya mempelajari kehidupan kelompok dalam sebuah kehidupan sosial masyarakat. Hal yang sama dikemukakan oleh Soekanto (1993) dan Taneko, bahwa dengan memahami kelompok sosial, kebudayaan, lembaga sosial, stratifikasi sosial, institusi sosial, kekuasaan dan wewenang, dapat dipakai untuk mengetahui bagaimana kesenian digunakan sebagai sarana berinteraksi antar individu, kelompok, dan unsur sosial yang lain berdasar pada pranata sosial yang dijadikan pedoman atau acuan dalam bersikap dan bertindak.

Partisipan adalah orang yang ikut serta atau berperan dalam dalam sebuah kegiatan (KBBI, 2015) misalnya tokoh seni, seniman, pemusik, pendengar musik dalam sebuah masyarakat. Dengan demikian partisipan seni adalah pelaku yang terlibat-- baik secara langsung maupun tidak langsung-- dalam perkembangan seni di masyarakatnya. Dalam masyarakat tradisional, partisipan yang terlibat dalam kesenian, bisa bersifat individu, atau semua anggota masyarakat.

Menurut Hauser (1979), ada perbedaan antara proses kesenian dalam masyarakat tradisi dengan masyarakat modern. Dalam studinya tentang hubungan strata sosial dengan corak seni yang hidup dalam masing-masing strata social, Hauser membagi beberapa corak budaya dan seni atas empat kategori antara lain seni elit, folk, pop dan seni massa. Seni rakyat (folk) adalah suatu seni yang datang dari suatu grup atau suatu kelompok masyarakat di saat masyarakat memiliki suatu kerangka sosial budaya yang dikembangkannya dan memiliki tradisi tertentu. Terbentuknya masyarakat dan budaya itu mungkin saja disebabkan oleh isolasi budaya, atau geografis; yang sebagian besar dari mereka, pada suatu saat, mengembangkan citarasa seni yang tinggi namun tidak terlepas dari kelompok masyarakatnya yang lebih besar. Seni folk, tradisi atau yang semacam ini pada masyarakat maju, cendrung disenangi oleh kalangan tua.

Folk art dapat berbentuk seni petani (the art of peasants), seni masyarakat pengembala domba (shepherds art), seni orang laut (sailors art), seni masyarakat nelayan (fisherfolk), seni masyarakat tukang (artisans) dan seni kelompok kecil pedagang (small tradespeople) yang hidup pada pusat budaya perkotaan (cultural urban centers) pada suatu bangsa yang tidak memiliki industri berat. Bentuk-bentuk masyarakat seperti ini ditemukan sejak abad Pertengahan di Eropa, dan terdapat di Amerika sejak abad ke 20, juga terdapat di Eropa Timur. Corak masyarakat seperti ini ditemukan pada pusat Asia dan Asia Timur, serta pada kotakota di Amerika Latin. Dengan demikian, Folk art secara konsisten mengembangkan produk yang khas, sesuai dengan selera lokal yang khas. Objekobjek seperti furniture, peralatan, permainan (toys), pakaian, perumahan (housing), peralatan musik (musical instruments), senjata, alat upacara (religious figurines), beberapa produk peralatan rumah tangga (household utensils) dapat dikategorikan sebagai hasil folk art. Oleh sebab itu pelaku seni folk, menurut kacamata atau standar modern, boleh jadi dapat dikatakan sebagai amatiran atau tidak terlatih secara profesional. Hal ini dapat dipahami, karena belum adanya pendidikan formal dalam masyarakat itu. Seniman rakyat folk artist umumnya mengikuti pola kehidupan masyarakatnya

Dalam masyarakat tradisional pelaku dan pencipta seni tidak diketahui (anonim), sedangkan dalam masyarakat modern pencipta seni, pemeran seni, pemusik, penyayi baru adalah individu yang diketahui. Umar Kayam (1981: 60) berpendapat bahwa dalam masyarakat modern, kesenian tradisional cepat atau lambat akan mengalami perubahan sesuai dengan kebutuhan serta kemampuan masyarakat pendukungnya yang baru, misalnya di masyarakat perkotaan. Tidak jarang kesenian baru di perkotaan itu bercorak "kichts" yaitu seni yang mencomot saja elemen-elemen seni tradisi yang berbeda dengan tradisi seni barat untuk menjadi kesatuan seni yang tidak jarang terlihat janggal dan kurang sempurna .walaupun usaha itu adalah untuk mencari "harmoni" dalam seni. 


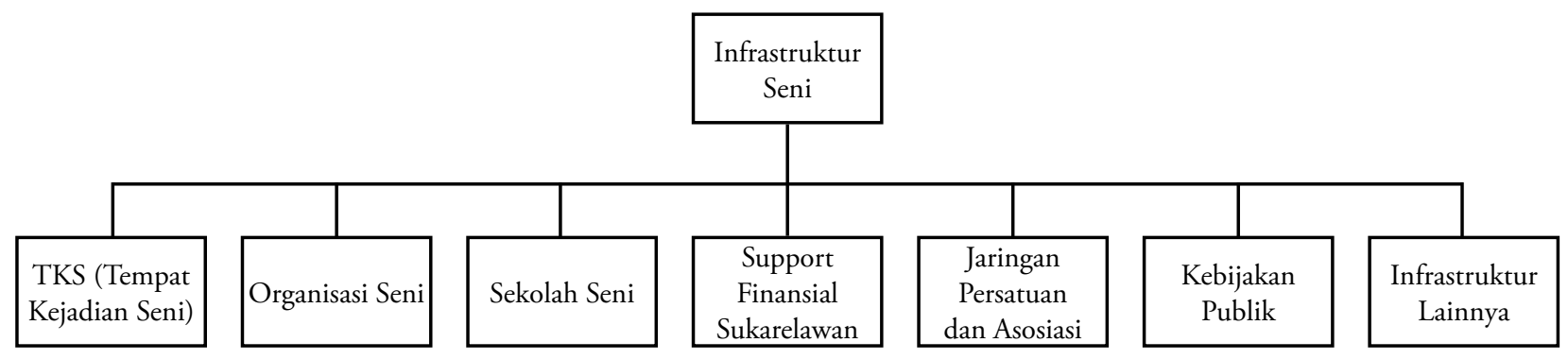

Gambar 1. Infrastruktur Seni dalam Masyarakat Modern (National Endowment for The Arts (NEA), 2012)

Perubahan dan perkembangan dari masyarakat tradisional menjadi masyarakat modern di perkotaan menyebabkan terbentuknya partisipan seni dan infrastruktur seni yang jelas dan tercatat dalam sejarah seni. Menurut NEA (2012) partisipan seni itu dapat berbentuk seperti penulis, kritikus, kurator seni, penyokong dana seni, kelompok atau grup seni, dan pengamat/ penikmat seni yang terlibat dan mengalami seni yang ada dalam masyarakatnya. Sedangkan infrastruktur seni adalah jaringan yang terlibat dalam pengembangan seni seperti tempat pagelaran seni, organisasi, sekolah seni, penyokong dana, asosiasi, dan sebagainya (Gambar 1).

\section{Pengembangan Musik Kreasi (Musik Baru)}

Menurut Clark (1998: 46-70), ada beberapa corak pengembangan seni di Asia, yaitu seni yang dipengaruhi oleh: (1) kolonialisme, (2) neo-kolonialisme, dan (3) non-kolonialisme. Pengembangan kesenian di Indonesia dan termasuk sumatera Barat tidak terlepas dari pengaruh Barat (kolonialisme), dan itu berlangsung sejak berdirinya Sekolah Raja (HIK) di tahun 1855 di Bukittinggi. Sumatera Barat. Pengembangan kesenian itu ada yang berasal individu nonakademik dan oleh kalangan akademik sebagai bagian dari infrastruktur seni di Sumatera Barat. Artinya, persentuhan seni tradisi dan seni barat itu berlangsung sejak lama. Misalnya bahasa Minang yang dipakai sekarang adalah perkembangan bahasa pergaulan di Sekolah Raja di Bukittingi sejak zaman kolonial.

Menurut Netrirosa (2003), pada masa kemerdekaan pengembangan seni oleh partisipan seni berubah ke corak baru, yaitu untuk memenuhi segmen komersial, misalnya dalam bentuk musik 'pop daerah' dan rata-rata hampir setiap etnik di Nusantara melakukannya. Kecenderungan yang terjadi dan yang menonjol dari hasil pengembangan itu adalah orientasi ke bentuk komposisi musik pop dengan melibatkan elemen-elemen musik barat yang bercampur dengan musik tradisi. Apresiasi terhadap musik barat cukup mengakar khususnya di Sumatera Barat dan umumnya di Indonesia, karena disebabkan mulai dari bangku sekolah Taman Kanak-kanak sampai dengan Sekolah Menengah Umum, pada umumnya apresiasi musik barat telah diikuti oleh murid-murid dalam mata pelajaran kesenian, maupun ekstra kurikuler. Kemudian faktor lainnya lagi yaitu media elektronik seperti TV, Radio, dan lain lain senantiasa memperdengarkan musik-musik pop yang pada dasarnya mengacu pada bentuk komposisi musik barat. Jadi terlihat bahwa partisipan seni itu lebih luas lagi karena melibatkan banyak pihak.

Umumnya lagu-lagu daerah yang berakar pada tradisi telah memakai iringan alat musik barat sehingga lagu-lagu daerah tersebut digolongkan kepada lagu pop daerah. Demikian juga instrumen musik sebagai pengiring lagu telah berkembang sesuai pula dengan keperluan dan selera masyarakat di daerah seperti mempergunakan Keyboard (organ) yang mempunyai kemampuan melahirkan berbagai macam bunyi bagaikan sebuah group band yang lengkap. Perkembangan musik pop di daerah Sumatera Barat sudah sangat jauh memasuki dunia musik pop yang berkembang secara umum di Indonesia, bahkan dengan cepat telah memanfaatkan ciri-ciri trend musik dunia. Pertemuan antara musik etnik yang beraneka ragam di Indonesia dengan musik dari Eropa Barat telah banyak memberikan warna musik yang baru, sehingga banyak komposer mencoba bereksplorasi 
serta melakukan kegiatan eksperimental dengan mengkolaborasikan dua kebudayaan tersebut, sehingga menghasilkan suatu musik baru atau musik kontemporer (Dewi, 2013: 104). Misalnya di Minangkabau bisa dilihat musik pop daerahnya yang cukup populer masa kini seperti lagu Kutang Barendo yang berasal dari seni vokal tradisional dendang Minangkabau dengan iringan Saluang (end blown flute) dengan teknik sirkulasi tiupan. Bahkan tidak kalah lagi diantara lagulagu pop daerah yang berangkat dari musik dan lagu tradisi itu telah dikembangkan lagi dengan memasukkan unsur-unsur 'rap' ke dalam komposisi musiknya dan terlihat bahwa lagu-lagu dengan memuat musik seperti di atas sudah berkembang.

\section{Lembaga Pendidikan Formal sebagai bagian Infrastruktur Seni}

Umumnya penciptaan musik tidak semata berangkat dari musik barat tetapi juga dari musik tradisi. Pengembangan dan kreativitas musik tradisi akan membawa sistem tradisi musik tersebut dilihat oleh partisipan seni agar dapat diterima dalam masyarakat masa kini. Oleh karena itu apa yang dilakukan oleh seniman mutlak memerlukan inspirasi karena ia merupakan komponen seni. Melalui bahan atau tema, dan motif yang diperoleh dari inspirasi itu, seniman pencipta akan dapat menghadirkan pengalamanpengalaman komunikatif yang diyakini melalui ciptaannya (Hajizar, 1994:6). Suatu karya kreativitas musik tentu memerlukan penikmat yang dapat berkomunikasi dengan karya tersebut, maka pertimbangan yang amat baik dipikirkan oleh seorang seniman atau komponis adalah penonton atau penikmat karya seni itu sehingga pemilihan terhadap kemungkinan pengembangan itu perlu penyesuaian dengan apresiasi penonton/penikmat (Murgiyanto, 1992:19).

Ada dua golongan pengembangan musik tradisional yang dilakukan oleh seniman-seniman yang ada di lembaga/institusi seni Minangkabau yaitu jenis komposisi musik dan jenis musik tari. Kedua jenis penggarapan musik itu sangat berbeda proses maupun teknik penggarapannya (Netrirosa, 2003). Menurut Edi Sedyawati (1990) dalam bu- kunya "Local Genius dalam Seni”, mengemukakan bahwa pengembangan musik tradisional Indonesia cenderung mempunyai konotasi kuantitatif daripada kualitatif, yaitu membesarkan volume penyajian, meluaskan wilayah penyajiannya dengan berpegang kepada mencari kemungkinan untuk mengolah dan memperbaharui wajah sebagai usaha pencapaian kualitatif (1981:50). Artinya pengembangan musik tradisi lebih menekankan aspek produksi seni musik, ketimbang aspek kualitasnya. Hal ini dapat dipahami karena persoalan pengembangan musik tradisional ke 'bentuk baru' (kreatif) adalah lebih bersifat yang mendasari penggarapan musiknya kepada kebebasan bersifat "eksperimental" dengan harapan hasil eksperimen itu bisa dan dapat diterima oleh partisipan seni lainnya (masyarakat pengguna).

Menurut Clark (1988), persentuhan seni Barat dengan seni lokal ikut mempengaruhi perkembangan seni di kawasan Asia yang secara teoritik meliputi (1) model transfer, (2) modalitas transfer, dan (3) tipe media budaya transfer (kolonial, neo-kolonial, dan non-kolonial). Menurut Clark model transfer seni yang dibawa sejalan dengan sifat kolonialisme dan kapitalisme yang berkembang sejak abad ke-15 setidaknya fungsi gaya dan teknik seni Eropa sebagai model untuk diadaptasi oleh budaya penerima umumnya tidak sama (Clark, 1988: 49). Dalam hal model transfer, Clark berpendapat dan memahami transfer sebagai proses penerimaan (resepsi) sifatnya dapat sementara dan sangat terbatas. Yaitu bentuk hubungan yang terstruktur antara berbagai hal dan sifat di kawasan Asia yang cukup beragam. Transfer seni itu pertama yaitu melalui penyampaian (komunikasi) dan penerimaan (resepsi) yaitu -- (1) reproduksi (copian) terhadap budaya dan seni umumnya, dan khususnya terhadap berbagai karya seni, (2) peniruan gaya dan teknik seni (pembelajaran)—dan atau oleh prakarsa seniman sendiri bersedia untuk menerima (reception). Dan yang kedua melalui mediator seperti penilaian (evaluasi) serta pasar seni (market) dalam kelompok elite, oleh publikasi atau media massa dan sebagainya.

Modalitas (modal) transfer atau "cara transfer itu dilakukan" dapat terjadi melalui tiga unsur yaitu (1) produser seni, (2) pendidik 
seni dan (3) konsumen seni (Clark, 1988: 52). Penghasil seni (produser) memandang kepada demand (kebutuhan) yang memberi peluang dan akses kepada munculnya corak kesenian. Sedangkan pendidik seni sebenarnya berada di bawah kepentingan kebutuhan lokal dan juga kepentingan institusi atau lembaga pemerintah. Sedangkan konsumen seni bertindak sebagai penerima (receiver) terdiri dari berbagai kalangan (kelas) masyarakat, dengan demikian audiens-nya bisa beragam.

\section{Pengembangan Seni Musik dan Ensambel Talempong Kreasi}

Talempong sudah lama dikenal di Minangkabau, bahkan tidak sedikit kalangan mengidentikkan talempong dengan segala sesuatu yang bernuansa Minangkabau (Miller dan Williams, 2008: 340342). Umumnya masyarakat tahu yang dimaksud dengan talempong ialah sejenis alat musik pukul berbentuk gong dalam ukuran kecil yang terbuat dari tembaga, kuningan dan timah (Hanefi, dkk., 2004). Talempong memiliki bentuk dan nama yang beraneka ragam. Nama dan bentuk alat musik tersebut sering disesuaikan dengan bahan baku yang dipakai pada proses pembuatannya, nama daerah asal alat musik, jumlah talempong yang digunakan, posisi alat saat dimainkan, serta penggunaannya (Depdikbud, 1985). Hal ini dapat dilihat dari beberapa nama yang diberikan pada alat musik tradisional tersebut, seperti: talempong batu di daerah Talang Anau Kabupaten 50 Kota yang terbuat dari batu, talempong batuang di Nagari Sungai Talang Kabupaten 50 Kota yang terbuat dari batuang (bambu), talempong aguang yang dipakai untuk upacara-upacara adat yang penuh dengan berbagai kebesaran (agung), talempong pacik yang dimainkan dengan dipacik (pegang) dan talempong kreasi yang merupakan musik sebagai hasil kreativitas orang yang dimainkan secara ritmis dan melodis. Hal ini mirip pada instrumen Gamelan Balaganjur yang dikelompokkan menjadi 3 bagian, yaitu kelompok melodis, kelompok ritmis, dan kelompok kolotomis (Ardana, 2013: 143).

Konsep seni tradisi dalam perjalanannya telah mengalami persentuhan dengan semua gejala yang berkembang dalam kehidupan masyarakat yang dinamis (Hanefi dkk, 2004: 67). Kondisi ini memaksa upaya-upaya pelestarian yang terus dilakukan saat ini untuk mengikuti proses-proses alami yang berlangsung di tengah masyarakat pendukung seni tradisi tersebut. Idealnya, mempertahankan kelestarian sebuah musik tradisi ialah mempertahankan semua bentuk dan aspek pendukung musik tersebut dan berupaya seminimal mungkin terjadinya perubahan-perubahan yang bersentuhan, baik langsung maupun tidak langsung pada musik tersebut (Bastomi, 1988). Namun upaya ideal tersebut tidaklah dapat dilakukan secara utuh, mengingat dinamika masyarakat yang menuntut untuk memasukkan unsur-unsur yang bersifat kreatif terhadap musik yang dipertunjukan.

Pengembangan musik tradisional ke arah musik kreasi baru cenderung dilakukan oleh partisipan seni yang kreatif dan berlatar belakang pendidikan formal dan non formal. Umumnya pengembangan berangkat dari musik tradisi yang digarap berdasarkan gagasan partisipan seni setelah memahami konsep-konsep berbagai musik yang dilibatkannya kedalam komposisi musiknya. Pengembangan musik tradisi ini memberi kebebasan kepada si pencipta berkreasi dan tidak merasa dibebani oleh etika tradisional. Kebebasan itu memang dimanfaatkan oleh para seniman mengekspresikan diri ke masyarakat, dan menyatakan diri sebagai seniman yang mewakili zamannya. Artinya, mengkreasikan musik-musik tradisi merupakan sebuah alternatif yang cukup baik dalam upaya mempertahankan musik tradisi di satu sisi dan tetap mengikuti perkembangan apresiasi dan persepsi seni masyarakat di sisi lain (Netrirosa, 2003). Kreasi dimaksud dapat dalam berbagai bentuk, disesuaikan dengan kemampuan dan keterbatasan yang dimiliki baik oleh seni tradisi maupun apresiasi dan persepsi seni masyarakat. Beberapa nama partisipan seni yang dianggap cukup berhasil mengkomunikasikan karya komposisi musiknya yang berpegang pada musik tradisional di Sumatera Barat antara lain adalah: Muhammad Halim, Hanife, Elizar dan Hajizar. Partisipan lainnya adalah Syofyani dari Grup Tari, Akhyar Adam, Yusaf Rahman, Murad St. Saidi, dan Irsyad Adam yang bergerak di bidang pendidikan seni Gambar 2). 


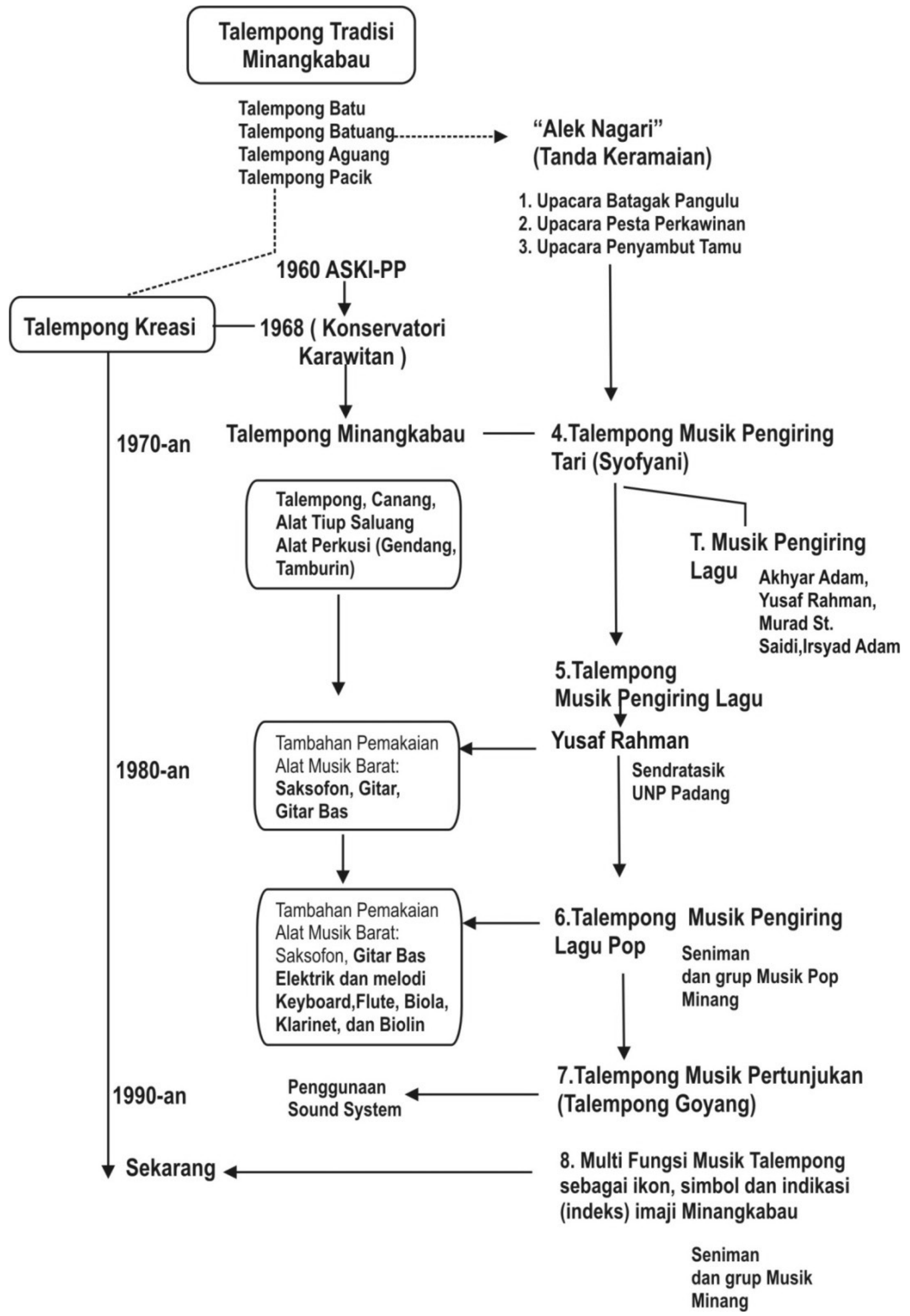

Gambar 2. Transformasi dan modernisasi musik talempong di Sumatera Barat 
Pada awalnya kehadiran talempong di dalam masyarakat selalu dikaitkan dengan atau upacara keadatan atau acara lainnya. Musik talempong bukan merupakan sesuatu yang sifatnya harus selalu ada dalam setiap upacara yang diadakan di tengah masyarakat. Namun, eksistensinya di tengah upacara tersebut selalu memberikan identitas pada masyarakat sebagai tanda adanya keramaian (alek nagari). Musik talempong sebagai musik daerah dapat dikenali daerah asal musik itu dan ciri identitas budaya masyarakatnya. Misalnya: ketika mendengarkan talempong pacik langsung diketahui kalau itu adalah musik daerah dari Minang atau bunyi gamelan itu dari daerah Jawa Tengah, sehingga dapat dikenalinya melalui karakter permainan talempong pacik atau gamelan melalui suara, irama, dan lagunya (Rustiyanti, 2014: 159).

Talempong kreasi menurut Bahar (2009: 179), adalah "musik yang dimainkan dengan ansambel talempong menggunakan sistem nada diatonik dan komposisi musik tersebut niscaya diolah berdasarkan pada sistem ilmu harmoni." Talempong kreasi ialah suatu bentuk seni tradisi yang telah mengalami berbagai persentuhan dan penyelarasan sedemikian rupa, sehingga menghadirkan bentuk musik baru yang lebih dinamis, memiliki fleksibilitas tinggi dan mampu menyesuaikan diri (adaptasi) dengan perkembangan apresiasi, persepsi, selera, dan keinginan masyarakat. Tidak hanya sebatas itu, talempong kreasi saat ini telah dimanfaatkan atau digunakan untuk berbagai kegiatan seni masyarakat yang lebih luas. Sehingga telah terjadi pergeseran dalam fungsi dan kegunaan seni tradisi tersebut di tengah masyarakat ke arah yang positif.

Bahar (2009: 179) menambahkan nama atau julukan talempong kreasi pada dasarnya adalah pembeda ansambel talempong yang telah mentradisi sebelumnya, apakah berbentuk ansambel gandang aguang maupun berbentuk ansambel talempong pacik. Dengan perkataan lain ialah bahwa musik "talempong kreasi baru" itu merupakan ujung perkembangan evolusioner dari tradisi musik talempong Minangkabau sebelumnya. Munculnya musik ini ialah pada bulan Agustus tahun 1968 dalam kaitannya dengan aktivitas Konservatori Karawitan (Kokar A dan B) Jurusan Minangkabau di Padangpanjang yang berdiri pada tahun 1960 (Sekarang Kokar-B menjadi ISI Padangpanjang).

Musik talempong kreasi pernah tumbuh dan berkembang pada tahun 1970-an. Talempong kreasi ini dikenal sebagai talempong Minangkabau. Instrumen yang digunakan adalah talempong, canang (jenis talempong berukuran sedikit lebih besar), beberapa alat tiup tradisional, dan alat perkusi seperti gendang dan tamburin. Hal ini sejalan dengan yang dikemukakan Bustamam (wawancara, 2 Januari 2011), Talempong kreasi atau juga dikenal dengan talempong goyang mulai berkembang di Sumatera Barat pada tahun 1970-an, di mana pada periode tersebut sanggar tari Syofyani mulai memperkenalkan kesenian ini kepada masyarakat sebagai musik iringan tari. Oleh karena digunakan untuk iringan tari, maka instrumen musik yang digunakan pun yang umum digunakan untuk mengiringi tari-tarian kreasi sanggar tari Syofyani, seperti: talempong, canang, gandang, saluang, dan bansi.

Alat musik talempong terdiri atas: satu set talempong melodi, satu set talempong pengiring rendah, satu set talempong pengiring tinggi, satu set canang pengiring rendah, dan satu set canang pengiring tinggi. Nada-nada canang berada satu oktaf di bawah nada-nada talempong. Talempong kreasi pada awal kelahirannya lebih banyak membawakan lagu-lagu yang berasal dari repertoar dendang tradisional yang biasanya diiringi alat musik saluang atau rabab. Lagu-lagu tersebut dibawakan sebagai pertunjukan musik instrumental dan sebagai musik iringan tari. Kalau pun ada kelompok talempong kreasi yang mengiringi nyanyian, baik lagu tradisional maupun lagu pop Minang itu hanya bersifat insidental. Beberapa sanggar seni telah berperan aktif menyajikan ansambel talempong kreasi sebagai pertunjukan musik instrumental untuk mengiringi lagu-lagu pop Minang, diantaranya ialah sanggar seni Citra Kembara. Menurut Fauriza (wawancara, 5 Januari 2011). Sanggar musik dan tari yang dikelolanya telah memanfaatkan kesenian talempong goyang untuk mengiringi beraneka jenis lagu, baik dendang tradisional yang biasanya diiringi alat musik saluang dan rabab maupun lagu pop Minang. Terkadang lagu-lagu daerah lain di Nusantara 
pun diiringi dengan talempong goyang. Bahkan musik pop Indonesia dan dangdut juga diiringi dengan talempong goyang. Dengan pemusik yang umumnya berasal dari mahasiswa Jurusan Pendidikan Sendratasik UNP, iringan lagu-lagu dengan talempong goyang tidak menjadi masalah pada sanggar musik dan tari yang dikelolanya.

Talempong kreasi lahir di Sumatera Barat sebagai hasil kerja bersama beberapa seniman musik Minangkabau. Kelahirannya tidak terlepas dari peran, diantaranya, Akhyar Adam, Yusaf Rahman, Murad St. Saidi, dan Irsyad Adam. Beliau-beliau ini pernah menjadi staf pengajar di ASKI/STSI/ISI Padangpanjang. Kemudian, dua orang diantaranya pindah mengajar. Yusaf Rahman mengajar di Jurusan Sendratasik IKIP Padang (sekarang UNP Padang), sedangkan Murad St. Saidi mengajar di SMKI Padang (sekarang SMKN 7 Padang). Masingmasing lembaga pendidikan tersebut menentukan talempong kreasi sebagai mata pelajaran atau mata kuliah. Menurut Bahar (wawancara, 10 Januari 2011), Talempong kreasi lahir sebagai hasil kerjasama beberapa seniman yang juga staf pengajar di ASKI/STSI Padangpanjang, yaitu: Akhyar Adam, Yusaf Rahman, Murad St. Saidi, dan Irsyad Adam. Mereka juga mengembangkan talempong kreasi pada sanggar-sanggar seni yang mereka bina. Bustamam (wawancara, 2 Januari 2011) mengemukakan:

Talempong kreasi di Jurusan Pendidikan Sendratasik UNP dikembangkan oleh Yusaf Rahman, salah seorang staf pengajar ASKI/ STSI/ISI Padangpanjang yang pindah ke Jurusan Sendratasik IKIP Padang. Beliau memberi warna tersendiri pada ensambel talempong kreasi ala Sendratasik, dengan memanfaatkan beberapa instrumen musik Barat ke dalam ensambel talempong kreasi, seperti: saksofon, biola, dan gitar bas. Talempong kreasi model ini juga dikembangkan di sanggar seni Syofyani.

Pada tahun 1980-an, perkembangan talempong kreasi cukup signifikan. Genre musik ini tidak hanya berfungsi sebagai pengiring tari dan permainan instrumental saja, tetapi sudah digunakan sebagai iringan lagu-lagu pop Minang. Kemudian, karena ada tuntutan agar pertunjukan talempong kreasi tampil lebih kuat, diperlukan alat pengeras suara, diperkuat dengan gitar bass elektrik. Kadangkala peralatan ini ditambah lagi dengan alat musik Barat lainnya, seperti keyboard, gitar melodi, saksofon, flute, dan biolin, sebagaimana dikemukakan Bandem (2006: 31) bahwa dalam penyajiannya, talempong kreasi dapat terdiri dari beberapa alat musik pendukung, seperti : talempong, canang, gandang, bansi, saluang dan alat musik lainnya. Namun dalam permainan talempong kreasi, tidaklah mutlak alat musik yang digunakan ialah alat musik tradisional Minangkabau. Ada kalanya kreasi yang tampil dikombinasikan dengan alat musik daerah lain di Indonesia maupun alat-alat musik Barat, seperti : gitar, biola, saksofon, klarinet, flute dan keyboard.

Pada tahun-tahun akhir 1980-an, lembagalembaga seni tersebut menemukan bentuk garapan baru yaitu penggabungan antara musik barat dengan musik tradisional. Komposisi musik penggabungan dua tradisi yang berbeda itu dilakukan oleh kerjasama antara siswa/mahasiswa dan staf pengajar bidang (jurusan) karawitan dengan siswa/mahasiswa dan staf pengajar jurusan musik (musik barat). Pada dasarnya kerjasama itu cenderung dalam praktik musik dan bukan dalam melahirkan konsep, sebab kehadiran musik tradisional berada di dalam kerangka komposisi musik barat (orkes simponi). Sebagaimana yang diketahui bahwa konsep komposisi musik barat telah diatur sedemikian rupa berdasarkan teori yang telah baku, sedangkan musik tradisional mempunyai sistem yang amat berbeda dengan teori musik barat. Jadi, usaha yang dilakukan berupa mencari titik-titik temu yang hasilnya tidak menyalahi secara total prinsip bangunan komposisi musik barat dan musik tradisional itu sendiri. Pada akhir tahun 1990-an, di samping iringan tari, talempong kreasi mulai berkembang ke arah pertunjukan musik dengan menampilkan penyanyi-penyanyi pop Minang yang tergabung dalam kelompok-kelompok tertentu. Menurut Hadi (wawancara, 15 Januari 2011):

Pada akhir tahun 1990-an, talempong kreasi mulai diminati sebagai sebuah pertunjukan musik, yang kehadirannya mengimbangi eksistensi musik orgen tunggal yang sedang 
marak ketika itu. Penyanyi-penyanyi pop Minang mulai beralih kepada musik hidup (live) dalam bentuk talempong kreasi sebagai pengiring dalam pertunjukannya. Pemanfaatan instrumen musik elektrik pun tidak bisa dihindari. Demikian pula sound system, sebagai pengeras suara. Besarnya peranan alat elektronik dalam pertunjukan talempong kreasi menjadi alasan utama terciptanya istilah baru, yaitu talempong goyang.

Alat musik elektronik seperti keyboard, gitar bass (sebagai kelengkapan peralatan talempong kreasi) menjadi semakin penting. Besarnya peranan alat elektronik tersebut dalam pertunjukan talempong kreasi menjadi alasan terciptanya istilah baru, yaitu talempong goyang. Kehadirannya cenderung menjawab perkembangan musik pop Minang dewasa ini. Kata "talempong" diartikan sebagai musik yang menggunakan alat musik utamanya, yaitu talempong. Kata goyang diartikan sebagai gerakan tubuh seperti menari mengikuti musik talempong. Tambahan kata goyang setelah kata talempong membangun anggapan bahwa musik jenis ini hadir dalam ranah musik pop. Memang secara tradisional tidak ada musik talempong Minangkabau yang dimainkan sambil bergoyang. Juga tidak ada penonton pertunjukan talempong kreasi tersebut yang menonton sambil bergoyang. Bergoyang sambil bernyanyi serta mengajak penonton mengikutinya, biasanya terjadi pada pertunjukan musik pop.

Para musisi talempong goyang, terutama yang memainkan alat musik, tidak selalu menggoyangkan badannya dalam pertunjukan. Yang sering menggoyangkan badan di antara mereka adalah pemain tamburin. Selain itu, para penyanyi yang tergabung dalam kelompok ini juga cenderung menggoyangkan badannya bilamana menyanyikan lagu-lagu yang mempunyai tempo yang agak cepat dan yang cepat. Lagu-lagu lambat biasanya dinyanyikan seperti laiknya penyanyi lagu pop membawakan lagu-lagu yang mempunyai tempo lambat. Gerakan tubuh dilakukannya untuk memperkuat ekspresi nyanyian, bukan menari. Yang tidak kalah pentingnya adalah pamakaian alat pengeras suara pada pertunjukan talempong goyang. Selama ini, pertunjukan talempong tradisi tidak menggunakan alat pengeras suara yang dikenal dengan istilah sound system. Para musisi bermain musik dengan kekuatan akustik saja.

Kehadiran sound system bagi pertunjukan talempong goyang justru menciptakan suatu semangat baru bagi musisinya. Mereka dianggap oleh masyarakat sebagai kelompok musik yang maju dan modern. Dengan pertolongan sound system, pertunjukan mereka dapat dilaksanakan di dalam dan di luar ruangan. Walaupun demikian, perlu disadari bahwa penggunaan teknologi sama sekali tidak bisa diartikan sebagai kemajuan jenis kesenian itu sendiri, hanya cara penyampaian yang berubah. Fauriza (wawancara, 5 Januari 2011), mengemukakan bahwa "saat ini umumnya pertunjukkan talempong kreasi untuk upacara resepsi pernikahan telah memanfaatkan sound system untuk mendukung kekuatan bunyinya”.

\section{Penutup}

Berdasarkan uraian di depan dapat disimpulkan bahwa pengembangan musik tradisional Talempong Kreasi dilakukan oleh partisipan seni yang kreatif bertujuan agar musik tradisional itu dapat menempatkan keberadaannya di cakrawala apresiasi masyarakat masa kini. Tetapi tidak jarang penekanannya baru dalam segi ekspreimen seni, produksi seni musik komersial dan belum lagi dari segi kualitas seni. Hal itu berlangsung sejak tahun 1970-an. Yang mempelopori Talempong tradisi ini pada awalnya adalah grup tari Sofyani dan masih dalam bentuk sederhana. Kemudian dikembangkan lagi dalam berbagai pihak baik oleh seniman-seniman akademik seperti Akhyar Adam, Yusaf Rahman, Murad St. Saidi, dan Irsyad Adam maupun yang berasal dari non akademik untuk tujuan komersial. Seniman-seniman akademik cenderung memilih pengembangan musik tradisional ke bentuk komposisi musik baru (kreasi) berdasarkan pendidikan formal yang diperolehnya dan diikuti oleh bakat. Sedangkan seniman lain atau non akademik berkembang atas dasar pengalaman.

Talempong kreasi ialah suatu bentuk seni tradisi yang telah mengalami berbagai persentuhan 
dan penyelarasan sedemikian rupa, sehingga menghadirkan bentuk musik baru yang lebih dinamis, memiliki fleksibilitas tinggi dan mampu menyesuaikan diri (adaptasi) dengan perkembangan apresiasi, persepsi, selera dan keinginan masyarakat. Tidak hanya sebatas itu, talempong kreasi saat ini telah dimanfaatkan atau digunakan untuk berbagai kegiatan seni masyarakat, sehingga telah terjadi sedikit pergeseran dalam fungsi dan kegunaan seni tradisi tersebut di tengah masyarakat kearah yang positif.

Dalam penyajiannya, talempong kreasi dapat terdiri dari beberapa alat musik yang sifatnya mendukung, seperti: talempong, canang, gandang, bansi, saluang dan alat musik lain sesuai keinginan kreativitas orang mengadakan pertunjukan. Namun dalam permainan talempong kreasi, tidaklah mutlak alat musik yang digunakan ialah alat musik tradisional Minangkabau. Ada kalanya kreasi yang tampil dikombinasikan dengan alat musik daerah lain di Indonesia maupun alat-alat musik Barat, seperti: gitar, biola, saksofone, clarinet, flute dan keyboard.

\section{Kepustakaan}

Ardana, I Ketut. 2013. "Pengaruh Gamelan terhadap Baleganjur Semaradana" dalam Resital Jurnal Seni Pertunjukan Vol. 14 No 2 Desember 2013: 141-152.

Arifni, Netrirosa. 2003. Musik Tradisional Minangkabau dari Masa ke Masa. Medan: USU Digitalized Library.

Bahar, Mahdi. 2003. "Musik Gendang di Minangkabau" dalam Jurnal Gendang Nusantara II.

Bastomi, Suwaji. 1988. Apresiasi Kesenian Tradisional. Semarang: IKIP Semarang Press.

Dasilva, Fabio. 1984. The Sociology of Music. Indiana: University of Notre Dame Press.

Depdikbud. 1985. Peralatan Hiburan dan Kesenian Tradisional Minangkabau Jakarta: Dirjen Kebudayaan Depdikbud

Dewi, Maria Octavia Rosiana. 2013. “Konsep Minimax Slamet Abdul Sjukur dalam Musik
Uwek-Uwek" dalam RESITAL: JURNAL SENI PERTUNJUKAN, Vol. 14 No 2 Desember 2013: 104-121.

Hauser, Arnold. 1982. The Sociology of Art. London: The Chicago Press

Hajizar. 1994. "Pengembangan Musik Tradisional Minangkabau dalam Era Globalisasi” [Kertas Kerja]. Padang: Departemen Pendidikan dan Kebudayaan.

Hanefi. 1997. "Perkembangan Muzik Tradisional Minangkabau" dalam Jurnal Gendang Nusantara II.

Jhon, Clark. 1988. Modern Asian Art. Honolulu: University of Hawaii Press.

Kayam, Umar. 1981. Seni Tradisi Masyarakat. Jakarta: Sinar Harapan.

National Endowment for The Arts (NEA, USA). 2012. http://arts.gov/sites/default/files/ how- the-us-funds-the-arts.pdf,di akses 20 Maret 2014, dan https://keithsawyer. wordpress.com/2012/09/

Miller, Terry E. dan Sean Williams (eds). 2008. The Garland Handbook of Southeast Asian Music. New York: Routledge.

Murgiyanto, Sal. 1992. "Seni Pertunjukan di Indonesia pada Masa Informasi Teknologi Canggih" [Kertas Kerja]. Yogyakarta:Institut Seni Indonesia (ISI), Yogyakarta.

Rustiyanti, Sri. 2014. "Musik Internal dan Eksternal dalam Kesenian Randai" dalam RESITAL: JURNAL SENI PERTUNJUKAN, Vol. 15 No 2 Desember 2014: 152-162.

Sedyawati, Edi. 1990. Local Genius Dalam Seni. Jakarta: Sinar Harapan.

Soekanto, Soerjono. 1993. Beberapa Teori Sosiologi Tentang Struktur Masyarakat. Jakarta: Raja Grafindo Persada.

\section{Informan}

Bustamam (65 th), Seniman dan akademisi

Fauriza (55 th.), Seniman dan Pimpinan sanggar musik dan tari Citra Kembara.

Mahdi Bahar (56 th), Seniman dan akademisi.

Hadi (55 th), Seniman 